\title{
Industry and environment: modeling the global production impact on $\mathrm{CO} 2$
}

\author{
N.I. Didenko ${ }^{1, *}$, D.F. Skripnuk ${ }^{1}$, and O.V. Mirolyubova ${ }^{1}$ \\ ${ }^{1}$ Peter the Great St. Petersburg Polytechnic University, St. Petersburg, Russia
}

\begin{abstract}
The article analyses the impact of global industrial production on $\mathrm{CO} 2$ emissions. The global economy comprises such industrial sectors as the primary economic sector (mining, wood processing industry), various processing industrial sectors, energy sector, housing and communal services and transportation sectors. We present the methodology of modelling global economy industrial impact on $\mathrm{CO} 2$ emissions. ADL-model (autoregressive distributed lags model) has been chosen as a theoretical basis. Eight variables affecting $\mathrm{CO} 2$ emissions per unit of production were chosen as exogenous: the reduction of forest area; the output of energy industries, utilities and extraction industries; wood processing industry; the volume of goods transported; the volume of transportation and communications sectors; the length of roads; the output of industries producing material resources. The primary statistic information on the endogenous and exogenous variables in many countries was collected. The endogenous and exogenous parameters for global economy based on the initial statistic information were defined as the geometric mean indices in the year $t$. The article presents a model of the global economy industries impact on $\mathrm{CO} 2$ emissions. The conclusions about the impact of industrial factors on $\mathrm{CO} 2$ emissions are drawn.
\end{abstract}

\section{Introduction}

The current state of the environment today is described as critical and there are certain factors that can lead to global environmental disasters. The first is pollution, environment contamination, the depletion of oxygen in the atmosphere, ozone gaps, etc. The second is the existence of radiation hazards, especially nuclear weapons, which is the most dangerous of all existing types of weapons. Its application can cause disastrous and irreversible damage to the natural environment. The third is the excessive use of available natural resources as well as traditional sources of energy and raw materials. The fourth factor is a rapid and virtually unregulated population growth. According to the forecast, the world population will reach 13 billion people by 2040. It is clear that with such a growth of the world population, the negative effects of human activities will sharply increase. Not only the population growth, which contributes to the negative effect on the environment, but also the need for more intensive extraction of nature resources leading to the larger accumulation of industrial waste, result in adverse effects on the biosphere. These four factors that lead to global environmental disasters, depend majorly on the industrial production in the global economy. Industry has an impact on the environment, and one of the influential factors is the growth of industrial production. The industrial development, the constant growth of the world population and consumption of natural resources lead to a continuous flow of various anthropogenic substances and compounds into the environment. Due to the production growth, the volume of emissions into the atmosphere has been steadily increasing. The concentration of carbon dioxide (CO2) in the atmosphere in the last decades is rapidly increasing.

\section{Overview of the relevant problem research}

According to up-to-date research, the level of carbon dioxide in the atmosphere is the highest in the last 800 thousand years. Because of the global industrial production emissions to the atmosphere have become a global environmental problem. With the accelerated pace of industrial production increases the environmental threat due to the various efforts to satisfy human needs. The only solution is to slow down the growth of industrial production at a level that does not harm the environment, which can be hardly possible. It is impossible to give up industrial growth and development, while maintaining gross national income at a constant level, as this will impact the quality of life. 
Why is it important to monitor how much $\mathrm{CO} 2$ the global industry emits into the atmosphere? The answer is that this gas is largely responsible for the increase of the greenhouse effect on our planet. The global balance of industrial emissions of carbon dioxide was measured for the first time in 1958 by Dave Keeling, the American scientist from the Scripps Institute of Oceanography. The researchers analyzing data on industrial $\mathrm{CO} 2$ emissions, the main greenhouse gas, united their efforts in Global carbon budget project. They study the main sources of atmospheric pollution, i.e. fuel and energy complex, processing industry and transport.

Grossman and Krueger [1] conducted an empirical study uncovering an inverted U-shaped relationship, also known as the EKC, between income and local air and water pollutants. Subsequent studies [2], [3], [4] were dedicated to measuring and analyzing the relationship between the environment, economy and industrial policies. Grossman and Krueger [5], Chimeli and Braden [6] examined the models of the effect of industrial production on the environment. Lahiri [7] examines the influence of the factors of income and environmental quality on the growth rates for open economies. The results are different from the standard convergence result for identical economies. This asymmetric outcome is then analyzed in terms of the scale, composition, and intensity effects known to underlie Kuznets' environmental curve. Stokey [8] explored how different production technologies affect the environment, while May, Stahl and Taisch [9] investigated how a firm's choice of alternate energy resources affects the environmental quality. $\mathrm{Xu}$ [10] analyzed the factors of competitiveness of environmentally friendly products and made the conclusion that the environmental standards reduce the international competitiveness of environmentally friendly products. Abatement technologies, analysis of the concentration of groundlevel ozone and its impact on ecosystems are considered in the works [11], [12]. Botta and Koźluk [13] studied the quantitative evaluation of the environmental policies in industrialized countries. The interaction of the environment, global industrial $\mathrm{CO} 2$ emissions and economic development is studied on the basis of different models. Liu and Ulgiati [14] have built a network model of the interaction of economy, energy and the environment. Robison [15], Ederington and Minier [16] developed a model of the influence of environmental factors and industrial emissions on the trade balance. Cole and Elliott [17] study the degree of the influence of capital, labor and industrial emissions on the foreign trade. Arce, López and Guan [18] consider the model of eco-efficient countries. The so-called postChina countries, distinguished by low wages and high economic growth, will replace China as the "world's factory". The aim of the paper is to assess the effect of these changes on global CO2 emissions. Meng, Liu, Guo, and Tao [19] developed the model quantifying the impact of international trade on the concentration of harmful substances in the urban economy. Sakamoto and Managi [20] defined energy efficiency and environmental quality as factors of comparative advantages in the industries, showing the empirical results of the impact of eco-efficiency indicators on industrial production. The reviews of the works of Carson [21], Vyboldina and Fedoseev [22], Didenko and Skripnuk [23], Tcvetkov and Strizhenok [24] indicate the need for further structural theoretical models of the relationship between industrial development and environmental situation.

\section{The approach to modeling the influence of industrial development on CO2 emissions}

\subsection{Theoretical model and its characteristics}

Autoregressive distributed lags (ADL-model) was chosen as a theoretical model, in which the current values of the series depend on the past values of the series, and from the current and past values of other time series. The model is generalized in the case of several exogenous variables. In general, we can assume that all exogenous variables are included in the model with the same number of lags, with the possible exception of a lag of some variables. ADL - model is as follows

$$
y_{t}=a_{0}+\sum_{i=1}^{n} a_{i} y_{t-i}+\sum_{j=0}^{q 1} b_{j} x_{t-i}^{1}+\ldots+\sum_{j=0}^{q k} b_{j} x_{t-i}^{k}+E_{t}
$$

where $k$ is a number of exogenous variables; $q$ is a number of lags in the $i$-th exogenous variable $(i=1,2$, .. $\mathrm{k})$; $\mathrm{n}$ is a lag depth for endogenous variable; Et is the residues developing the white noise.

This model suggests that, if at a certain time $t$, the independent variable $x_{t}$ changes, then this change will impact the value of the variable $y_{t}$ at the following time points.

\subsection{Data}

The initial data was processed following two stages: a) the analysis and selection of endogenous and exogenous variables that correspond to the analyzed process and reflect the essence of the problem; b) the collection of statistical information for the selected variables. The analysis and the choice of endogenous and exogenous variables. The endogenous variable, i.e. the emissions $\mathrm{CO} 2$ per unit of production, g/USD (grams per USD in constant prices) is set, per se being a specific target. We denote emissions per product unit at a time $t$ point as $y_{t}^{2}$. Our task is to build the relationship $y_{t}^{2}$ on the past values of the series $y_{t-j}^{2}$ and of the past values of other exogenous variables.

Exogenous variables were $y_{t}^{2}$ chosen from the following list: $X_{1 t}^{1}$ - GDP, World, US \$ Per Capita; $X_{2 t}^{1}$ - Employed Population, World, Unit 000; $X_{3 t}^{1}$ Economically Active Population, World, Unit 000; $X_{4 t}^{1}$ - Exports (fob) by Commodity + Imports (cif) by 
Commodity, World, USD million; $X_{1 t}^{2}$ - Energy, Utilities and Recycling: Production (turnover) MSP, USD million, USD million; $X_{2 t}^{2}$ - Primary Materials. Forestry, Production (turnover) MSP, USD million, Million net ton-kilometres; $X_{3 t}^{2}$ - Road Freight Traffic, Million net tonne-kilometres; $X_{4 t}^{2}$-Transport and Communications: Production (turnover) MSP, USD million, USD million; $X_{5 t}^{2}$ - Road Network, Kilometres; $X_{6 t}^{2}$ - Material Resource Productivity, USD per $\mathrm{kg}$ in constant prices; $X_{1 t}^{3}$ - Greenhouse Gas Emissions from Energy, 000 tonnes of $\mathrm{CO} 2$ equivalent; $X_{2 t}^{3}$ - Extraction of Crude Petroleum and Natural Gas, USD million; $X_{3 t^{-}}^{3}$ Mining of Coal and Lignite; Extraction of Peat, USD million; $X_{4 t}^{3}$ - Energy, Utilities and Recycling: Production (turnover) MSP, USD million; $X_{5 t}^{3}$ - Railway Freight Traffic, Million tonnekilometres; $X_{6 t}^{3}$ - Waste Generated by Manufacturing, 000 tonnes; $X_{1 t}^{4}$ - Machinery for Food, Beverage and Tobacco Processing: Production (turnover) MSP, USD million; $X_{2 t}^{4}$ - Agricultural and Forestry Machinery: Production (turnover) MSP, USD million; $X_{3 t}^{4}$ - Animal Husbandry. Industrial: Primary Materials, USD million; $X_{4 t}^{4}$ - Arable Land, $000 \mathrm{sq} \mathrm{km} ; X_{5 t}^{4}$ - Animal waste - Production, Terajoules; $X_{6 t}^{4}$ - Waste Generated by Agriculture, Forestry and Fishing, 000 tonnes; $X_{1 t}^{5}$ Methane emissions (kt of equivalent); $X_{2 t}^{5}$ - Nitrous oxide emissions (thousand metric tons of equivalent); $X_{3 t^{-}}^{5}$ - Greenhouse Gas Emissions, 000 tonnes of equivalent; $X_{4 t}^{5}$ - $\mathrm{CO} 2$ Emissions from the Consumption and Flaring of Fossil Fuels, 000 tonnes; $X_{5 t}^{5}$ - Waste Generated by Electricity, Gas, Steam and Air Conditioning Supply, 000 tonnes; $X_{6 t}^{5}$ - Waste Generated by Households, 000 tonnes; $X_{1 t}^{6}$ - Annual fresh water withdrawals, $(\%$ of internal resources $) ; X_{2 t}^{6}$ Agricultural Materials and Live Animals Wholesale: Retail and Wholesale, USD million; $X_{3 t}^{6}$ - Farm Animal Feeds: Production (turnover) MSP, USD million; $X_{4 t}^{6}{ }^{-}$ Hydrological Disasters, USD million; $X_{5 t}^{6}$ - Total population supplied by water supply industry, $\% ; X_{6 t}^{6}$ Renewable freshwater resources, million cubic metres; $X_{7 t}^{6}$ - Net freshwater supplied by water supply industry, million cubic metres; $X_{1 t}^{7}$ - Agricultural Land, 000 sq km; $X_{2 t}^{7}$ - Total Population, 000 per.; $X_{3 t}^{7}$-Wood and Paper Products: Production (turnover) MSP, USD million; $Y_{t}^{7}$ - Forest Land, $000 \mathrm{sq} \mathrm{km}$.

As a result of the analysis of the list of indicators, the following seven variables impacting $y_{t}^{2}$ - the emissions $\mathrm{CO} 2$ per production unit were chosen as exogenous: $Y_{t}^{7}$; $X_{1 t}^{2}, X_{2 t}^{2}, X_{3 t}^{2}, X_{4 t}^{2}, X_{5 t}^{2}, X_{6 t}^{2}$.

Data. The data was collected for the period from 1998 to 2015 . It contains the values of endogenous and exogenous variables for the corresponding year in different countries. The data was taken from the following sources: Euromonitor Passport Database, http://www.euromonitor.com/; World Bank Open Data, http://data.worldbank.org/.

\subsection{Methodology of the model's empirical verification}

The structural form of the model is the following:

$$
\left\{y_{t}^{2}=f\left(Y_{t}^{7}, X_{1 t}^{2}, X_{2 t}^{2}, X_{3 t}^{2}, X_{4 t}^{2}, X_{5 t}^{2}, X_{6 t}^{2}\right)\right\}
$$

The empirical verification of the model consisted of several stages. Below are the main stages.

The first stage of the method was the development of the above form of ADL-model with the given endogenous and chosen exogenous variables.

For the structural form of ADL- model (2) the reduced form is as follows:

$y_{t}^{2}=a_{0}+\sum_{i=1}^{T} a_{i} y_{t-i}^{2}+\sum_{i=1}^{T} b_{t-1-i} Y_{t-1-i}^{7}+\sum_{i=1}^{T} \sum_{k=1}^{6} c_{k, t-1-i} X_{k, t-1-i}^{2}$

The second stage of the method was the calculation of endogenous and exogenous variables of the model for the global economy. The initial statistic information on endogenous and exogenous variables was collected for different countries. Endogenous and exogenous parameters for global economy were defined as geometric mean indices for different countries in the year $t$. The calculation was performed in Microsoft Excel. This calculation resulted in developing timeseries data for endogenous and exogenous variables for the period from 1997 to 2015 .

At the third stage of the method, a test of temporal series of variables for stationarity was carried out using the Dickey-Fuller test. The Dickey-Fuller test is finding a coefficient of the autoregressive equation:

$$
y_{t}=a y_{t-1}+\varepsilon_{t}
$$

where $y_{t}$ is a temporal series, $\varepsilon_{t}$ is an error.

If $|\mathrm{a}|<1$ than the series is stationary. If $a=1$ than the process has a unit root and in this case the series is nonstationary and is an integrated temporal series of the first order [25]. 
The fourth stage included a test of autocorrelation of an endogenous variable for selecting lags which have a strong correlative relationship with the index value in the last period; a test of strength of the endogenous variable's relationship with exogenous variables; a test of the exogenous variables for multicollinearity; a test of significance of the autocorrelation coefficients using the Ljung-Box test; a test of pair correlation coefficients for significance using a Student's t-test for indices.

At the fifth stage, the model coefficients were determined using the regression analysis. The significance and coefficients of the regression equation were tested. The equation was tested for certainty using an F-test and the determination coefficient. The significance of the regression equation's coefficients was tested using a Student's t-test. On the basis of the obtained coefficients, theoretical values of the endogenous variables of the model in a certain year were determined. The conclusions were made.

\section{Empirical testing of the model}

The quantitative testing of the model is carried out according to the developed method which is given above.

Endogenous and exogenous variables are given in Table 1.

Table 1. Endogenous and exogenous variables of the model.

\begin{tabular}{|c|c|c|c|c|c|c|c|c|}
\hline & $\mathbf{y}_{t}^{2}$ & $\begin{array}{r}7 \\
\mathbf{y}_{t}^{7}\end{array}$ & $\begin{array}{c}2 \\
\mathbf{x}_{1 t}\end{array}$ & $\begin{array}{c}2 \\
\mathbf{x}_{2 t}\end{array}$ & $\begin{array}{c}2 \\
\mathbf{x}_{3 t}\end{array}$ & $\begin{array}{c}2 \\
\mathbf{x} \\
4 t\end{array}$ & $\mathbf{2} \begin{array}{c}2 \\
5 t\end{array}$ & $\begin{array}{c}2 \\
\times 6 t\end{array}$ \\
\hline 2015 & 755.8 & $\begin{array}{l}3998 . \\
4\end{array}$ & $\begin{array}{r}10876 \\
990.0\end{array}$ & $\begin{array}{r}270 \\
392.5 \\
\end{array}$ & $\begin{array}{r}13628 \\
785.7\end{array}$ & $\begin{array}{l}9961 \\
604.0\end{array}$ & $\begin{array}{r}38934 \\
149.6\end{array}$ & 00.9 \\
\hline 2014 & 848.8 & $\begin{array}{r}40 \\
005.4\end{array}$ & $\begin{array}{r}12749 \\
580.0\end{array}$ & $\begin{array}{r}283 \\
001.4\end{array}$ & $\begin{array}{r}13325 \\
858.5\end{array}$ & $\begin{array}{r}10354 \\
430.0\end{array}$ & $\begin{array}{r}38468 \\
770.3\end{array}$ & 00.9 \\
\hline 2013 & 944.1 & $\begin{array}{r}40 \\
040.8\end{array}$ & $\begin{array}{r}12927 \\
950.0\end{array}$ & $\begin{array}{r}274 \\
270.9\end{array}$ & $\begin{array}{r}12625 \\
047.9\end{array}$ & $\begin{array}{r}10032 \\
770.0\end{array}$ & $\begin{array}{r}37865 \\
778.3\end{array}$ & 00.8 \\
\hline 2012 & 1111.7 & $\begin{array}{r}40 \\
073.8 \\
\end{array}$ & $\begin{array}{r}12681 \\
730.0 \\
\end{array}$ & $\begin{array}{r}262 \\
075.0 \\
\end{array}$ & $\begin{array}{r}12793 \\
170.7 \\
\end{array}$ & $\begin{array}{l}9656 \\
216.0 \\
\end{array}$ & $\begin{array}{r}37089 \\
303.3 \\
\end{array}$ & 00.8 \\
\hline 2011 & $\begin{array}{lll}1 & 183.1 \\
\end{array}$ & $\begin{array}{r}40 \\
106.7 \\
\end{array}$ & $\begin{array}{r}12300 \\
570.0 \\
\end{array}$ & $\begin{array}{r}263 \\
658.3 \\
\end{array}$ & $\begin{array}{r}11927 \\
459.4 \\
\end{array}$ & $\begin{array}{r}9594 \\
466.0 \\
\end{array}$ & $\begin{array}{r}36632 \\
863.4 \\
\end{array}$ & 00.8 \\
\hline 2010 & 1466.1 & $\begin{array}{r}39 \\
867.3 \\
\end{array}$ & $\begin{array}{r}10182 \\
960.0 \\
\end{array}$ & $\begin{array}{r}232 \\
551.5 \\
\end{array}$ & $\begin{array}{r}10950 \\
618.8 \\
\end{array}$ & $\begin{array}{l}8507 \\
177.0 \\
\end{array}$ & $\begin{array}{r}36196 \\
054.8 \\
\end{array}$ & 00.8 \\
\hline 2009 & 1684.6 & $\begin{array}{r}39 \\
899.6 \\
\end{array}$ & $\begin{array}{l}8531 \\
825.0\end{array}$ & $\begin{array}{r}203 \\
412.3 \\
\end{array}$ & $\begin{array}{r}10169 \\
687.2 \\
\end{array}$ & $\begin{array}{l}7738 \\
202.0 \\
\end{array}$ & $\begin{array}{r}35629 \\
943.2 \\
\end{array}$ & 00.7 \\
\hline 2008 & 1751.6 & $\begin{array}{r}39 \\
931.9 \\
\end{array}$ & $\begin{array}{r}10470 \\
040.0\end{array}$ & $\begin{array}{r}220 \\
305.4\end{array}$ & $\begin{array}{l}9912 \\
228.0\end{array}$ & $\begin{array}{l}8361 \\
470.0 \\
\end{array}$ & $\begin{array}{r}34899 \\
714.6\end{array}$ & 00.8 \\
\hline 2007 & 1858.6 & $\begin{array}{r}39 \\
964.2 \\
\end{array}$ & $\begin{array}{l}8435 \\
699.0\end{array}$ & $\begin{array}{r}209 \\
197.7 \\
\end{array}$ & $\begin{array}{r}7694 \\
557.3\end{array}$ & $\begin{array}{r}7538 \\
459.0 \\
\end{array}$ & $\begin{array}{r}34422 \\
332.7\end{array}$ & 00.7 \\
\hline 2006 & 2305.4 & $\begin{array}{r}39 \\
996.4 \\
\end{array}$ & $\begin{array}{l}7358 \\
770.0\end{array}$ & $\begin{array}{r}172 \\
286.4\end{array}$ & $\begin{array}{r}7274 \\
432.0 \\
\end{array}$ & $\begin{array}{l}6651 \\
129.0 \\
\end{array}$ & $\begin{array}{r}33842 \\
412.1\end{array}$ & 00.7 \\
\hline 2005 & 2797.4 & $\begin{array}{r}39 \\
997.7\end{array}$ & $\begin{array}{l}6371 \\
666.0\end{array}$ & $\begin{array}{r}151 \\
341.1 \\
\end{array}$ & $\begin{array}{l}6916 \\
817.7\end{array}$ & $\begin{array}{l}6068 \\
108.0 \\
\end{array}$ & $\begin{array}{r}33346 \\
998.2 \\
\end{array}$ & 00.7 \\
\hline 2004 & 3 374.4 & $\begin{array}{r}40 \\
041.6\end{array}$ & $\begin{array}{l}5143 \\
339.0\end{array}$ & $\begin{array}{r}141 \\
165.5\end{array}$ & $\begin{array}{l}6682 \\
466.2\end{array}$ & $\begin{array}{l}5522 \\
844.0\end{array}$ & $\begin{array}{r}32879 \\
283.3\end{array}$ & 00.7 \\
\hline 2003 & 4501.3 & $\begin{array}{r}40 \\
085.5 \\
\end{array}$ & $\begin{array}{l}4240 \\
525.0\end{array}$ & $\begin{array}{r}121 \\
836.7\end{array}$ & $\begin{array}{r}6289 \\
926.3 \\
\end{array}$ & $\begin{array}{l}4879 \\
918.0\end{array}$ & $\begin{array}{r}32545 \\
009.2\end{array}$ & 00.7 \\
\hline 2002 & 5407.6 & $\begin{array}{r}40 \\
129.4\end{array}$ & $\begin{array}{l}3614 \\
337.0\end{array}$ & $\begin{array}{r}108 \\
938.5\end{array}$ & $\begin{array}{l}6103 \\
291.3 \\
\end{array}$ & $\begin{array}{l}4295 \\
864.0\end{array}$ & $\begin{array}{r}32080 \\
270.7\end{array}$ & 00.7 \\
\hline 2001 & 7550.9 & $\begin{array}{r}40 \\
173.3 \\
\end{array}$ & $\begin{array}{l}3645 \\
993.0\end{array}$ & $\begin{array}{r}106 \\
174.2\end{array}$ & $\begin{array}{l}5901 \\
409.5\end{array}$ & $\begin{array}{l}4159 \\
924.0\end{array}$ & $\begin{array}{r}31601 \\
067.8\end{array}$ & 00.7 \\
\hline 2000 & 8163.9 & $\begin{array}{r}40 \\
217.2\end{array}$ & $\begin{array}{l}3680 \\
902.0\end{array}$ & $\begin{array}{r}111 \\
296.8\end{array}$ & $\begin{array}{l}5748 \\
609.5\end{array}$ & $\begin{array}{l}4130 \\
435.0\end{array}$ & $\begin{array}{r}30681 \\
228.0\end{array}$ & 00.6 \\
\hline 1999 & $\begin{array}{r}12 \\
709.9\end{array}$ & $\begin{array}{r}40 \\
280.6\end{array}$ & $\begin{array}{l}3099 \\
467.0\end{array}$ & $\begin{array}{r}112 \\
658.6\end{array}$ & $\begin{array}{l}5562 \\
868.2\end{array}$ & $\begin{array}{l}3927 \\
919.0\end{array}$ & $\begin{array}{r}30334 \\
900.1\end{array}$ & 00.6 \\
\hline 1998 & $\begin{array}{r}18 \\
346.8\end{array}$ & $\begin{array}{r}40 \\
351.5 \\
\end{array}$ & $\begin{array}{l}2925 \\
955.0\end{array}$ & $\begin{array}{r}109 \\
677.0\end{array}$ & $\begin{array}{l}5331 \\
136.1\end{array}$ & $\begin{array}{l}3762 \\
397.0 \\
\end{array}$ & $\begin{array}{r}29938 \\
785.4 \\
\end{array}$ & 00.6 \\
\hline 1997 & $\begin{array}{r}21 \\
717.7\end{array}$ & $\begin{array}{r}40 \\
422.4\end{array}$ & $\begin{array}{l}3114 \\
773.0\end{array}$ & $\begin{array}{r}115 \\
947.4\end{array}$ & $\begin{array}{l}5115 \\
996.2\end{array}$ & $\begin{array}{l}3726 \\
223.0\end{array}$ & $\begin{array}{r}29684 \\
185.1\end{array}$ & 00.7 \\
\hline
\end{tabular}

The test of temporal series for stationarity was carried out using the Dickey-Fuller test.

The Dickey-Fuller test aimed to find the coefficient of the first-order autoregressive equation in Excel. For a temporal series with an endogenous variable - $\mathrm{CO} 2$ emissions per one production unit, gr./USD (grams per USD in constant prices) $\left(\mathrm{Y}_{2 \mathrm{t}}\right)$ the coefficient of the autoregressive equation $\mathrm{a}=0.67829393$ $\left(t_{T}=2.39239415 \leq t_{p}=26.015215\right)$. Consequently, the temporal series is stationary.

Similarly, for exogenous variables:

For $\mathrm{Y}_{7 \mathrm{t}}-$ Forest Land, 000 sqkm., the coefficient of the autoregressive equation $\mathrm{a}=0.718665\left(\mathrm{t}_{\mathrm{T}}\right.$ $=2.39239415 \leq \mathrm{t}_{\mathrm{p}}=6.306241$ ). Consequently, the temporal series is stationary.

For $X_{1 t}^{2}$ - the coefficient of the autoregressive equation $\quad \mathrm{a}=0.59011572 \quad\left(\mathrm{t}_{\mathrm{T}} \quad=2.39239415 \quad \leq_{\mathrm{t}_{\mathrm{p}}}\right.$ $=22.6332371$ ). Consequently, the temporal series is stationary. For $X_{2 t}^{2}$ - the coefficient of the autoregressive equation $\mathrm{a}=0.47480575 \quad\left(\mathrm{t}_{\mathrm{T}}=1.6746759\right.$ $\leq t_{p}=18.2106505$ ). Consequently, the temporal series is stationary. For $X_{3 t}^{2}$ - the coefficient of the autoregressive equation $\quad \mathrm{a}=0.54263514 \quad\left(\mathrm{t}_{\mathrm{T}} \quad=1.91391532 \leq\right.$ $\mathrm{t}_{\mathrm{p}}=20.812172$ ). Consequently, the temporal series is stationary. For $X_{4 t}^{2}$ - the coefficient of the autoregressive equation $\quad \mathrm{a}=0.61046453 \quad\left(\mathrm{t}_{\mathrm{T}}\right.$ $\left.=2.15315473 \leq t_{p}=23.4136935\right)$. Consequently, the temporal series is stationary. For $X_{5 t}^{2}$ - the coefficient of the autoregressive equation $\mathrm{a}=0.48158869 \quad\left(\mathrm{t}_{\mathrm{T}}\right.$ $\left.=1.69859985 \leq t_{p}=18.4708027\right)$. Consequently, the temporal series is stationary. For $X_{6 t}^{2}$ - the coefficient of the autoregressive equation $\mathrm{a}=0.67151099 \quad\left(\mathrm{t}_{\mathrm{T}}\right.$ $\left.=2.36847021 \leq t_{p}=25.7550629\right)$. Consequently, the temporal series is stationary.

According to the results of the Dickey-Fuller test, all temporal series are stationary.

The test of exogenous variables for multicollinearity was carried out in Excel. Correlation coefficients are given in table2.

Table 2. Correlation coefficients of exogenous variables.

\begin{tabular}{|c|c|c|c|c|c|c|c|}
\hline & Y7 & X2-1 & X2-2 & X2-3 & X2-4 & X2-5 & X2-6 \\
\hline Y7 & 1 & & & & & & \\
\hline X2-1 & $\begin{array}{r}- \\
0.65167 \\
53 \\
\end{array}$ & 1 & & & & & \\
\hline X2-2 & $\begin{array}{r}- \\
0.62433 \\
32 \\
\end{array}$ & $\begin{array}{r}0.98825 \\
107 \\
\end{array}$ & 1 & & & & \\
\hline X2-3 & $\begin{array}{r}- \\
0.59748 \\
91\end{array}$ & $\begin{array}{r}0.95950 \\
49 \\
\end{array}$ & $\begin{array}{r}0.97252 \\
26\end{array}$ & 1 & & & \\
\hline X2-4 & $\begin{array}{r}- \\
0.68759 \\
14\end{array}$ & $\begin{array}{r}0.99151 \\
663\end{array}$ & $\begin{array}{r}0.69421 \\
101 \\
\end{array}$ & $\begin{array}{r}0.97276 \\
801 \\
\end{array}$ & 1 & & \\
\hline X2-5 & $\begin{array}{r}- \\
0.63362 \\
96\end{array}$ & $\begin{array}{r}0.95221 \\
146\end{array}$ & $\begin{array}{r}0.66163 \\
634\end{array}$ & $\begin{array}{r}0.97056 \\
943\end{array}$ & $\begin{array}{r}0.67884 \\
75\end{array}$ & 1 & \\
\hline X2-6 & $\begin{array}{r}- \\
0.56508 \\
71 \\
\end{array}$ & $\begin{array}{r}0.84833 \\
017\end{array}$ & $\begin{array}{r}0.56684 \\
673 \\
\end{array}$ & $\begin{array}{r}0.89165 \\
416 \\
\end{array}$ & $\begin{array}{r}0.57399 \\
322 \\
\end{array}$ & $\begin{array}{r}0.59673 \\
6593 \\
\end{array}$ & \\
\hline
\end{tabular}


Table 3. Calculated values of the student's t-test for the indices.

\begin{tabular}{|r|r|r|r|r|}
\hline Y7 & Y7 & X2-2 & X2-4 & X2-5 \\
\hline X2-2 & 3.295352871 & & & \\
\hline $\mathrm{X} 2-4$ & 3.904449189 & 3.976686 & & \\
\hline $\mathrm{X} 2-5$ & 3.376937014 & 3.638178 & 3.811846551 & \\
\hline $\mathrm{X} 2-6$ & 2.824031177 & 2.836979 & 2.890157728 & 3.066168975 \\
\hline
\end{tabular}

With the significance level $\alpha=0.05$, numbers of the degree of freedom are $n-2=17, T_{\text {table }}=2.11$. Since in all cases $T_{\text {calc }}>T_{\text {table }}$, the coefficients are considered significant.

Lags of the endogenous variable, which have a strong correlational relationship with the index value in the last period, were selected by calculating autocorrelation coefficients. The test of significance of the autocorrelation coefficients was carried out using the Ljung-Box test.

According to both the Box-Pierce test and the LjungBox test, if $Q>\chi_{1-a, m}^{2}$ the coefficients are considered significant, $\chi_{1-a, m}^{2}$ is determined according to the table. Autocorrelation analysis was done with the Statistica software. The results are given in table 4 .

Table 4. Autocorrelation coefficients of the endogenous variable.

\begin{tabular}{|r|r|r|r|}
\hline Autocorr. & St. error & Ljung-Box Q & $\mathbf{p}$ \\
\hline 0.805588 & 0.240906 & 11.18228 & 0.000827 \\
\hline 0.565891 & 0.231455 & 17.15996 & 0.000188 \\
\hline 0.316687 & 0.221601 & 19.20225 & 0.000249 \\
\hline 0.081502 & 0.211289 & 19.35104 & 0.000672 \\
\hline-0.136611 & 0.200446 & 19.81553 & 0.001356 \\
\hline-0.205442 & 0.188982 & 20.99731 & 0.001841 \\
\hline-0.269033 & 0.176777 & 23.31343 & 0.001507 \\
\hline-0.325823 & 0.163663 & 27.27677 & 0.000636 \\
\hline
\end{tabular}

Since the Q-statistic of Ljung-Box is more accurate, it is more preferable for the analysis. Autocorrelation analysis in Statistica, apart from autocorrelation coefficients, also automatically calculates the Q-statistic of Ljung-Box and significance for each coefficient. The significance test by the Q-statistic of Ljung-Box equals to $>\chi_{0.95,3}^{2}$. The coefficients are significant. The endogenous parameter $y_{t}^{2}$ signifies the dependence from one previous period $y_{t-1}^{2}$.

The lags of each exogenous variable closely connected with the endogenous variable $y_{t}^{2}$ were chosen by calculating correlation coefficients. The significance test of correlation coefficients was carried out using the Ljung-Box Q test.

For endogenous variable $y_{t}^{2}$ with only one exogenous variable $y_{t-1}^{7}$ (Forest Land), with lag $t-1$, the correlation coefficient was equal to 0.798856 and significant $(\mathrm{p}=0.000914$, the Q-statistic of Ljung-Box $\left.=10.99617>\chi_{0.95,3}^{2}\right)$. Endogenous variable $y_{t}^{2}$ signifies the dependence from one previous period of exogenous variable $y_{t-1}^{2}$.

The correlation coefficients of endogenous variable $y_{t}^{2}$ with other lags of exogenous variables are less than $|07|$ and the coefficients are not significant.

Taking into account previous analyses, the ADLmodel has the following form:

$$
\begin{aligned}
& y_{t}^{2}=a_{0}+a_{1} y_{t-1}^{2}+a_{2} y_{t}^{7}+a_{3} y_{t-1}^{7}+a_{4} x_{2, t}^{2}+a_{5} x_{4, t}^{2} \\
& +a_{6} x_{5, t}^{2}+a_{7} x_{6, t}^{2}(5)
\end{aligned}
$$

The model's coefficients were found in Excel using the regression analysis. Besides, the certainty check of the regression equation was carried out basing on a Fisher's F-test, the equation coefficients were calculated by the OLS method, the coefficients' certainty was assessed on the basis of the Student's t-test.

For equation (5) $\mathrm{F}_{\text {table }} 9.01<\mathrm{F}_{\text {actual }} 62.503378 \Rightarrow>$ the model is statistically significant, the regression equation is reliable for the significance level of $\alpha=0.05, \mathrm{R}^{2}=$ 0.97765481 and the equation has the form of

$$
\begin{aligned}
& y_{t}^{2}=40717.9548+0.83918843 y_{t-1}^{2}-0.1956906 y_{t}^{7}- \\
& 0.8451041 y_{t-1}^{7}-0.0330472 x_{2, t}^{2}+0.00100218 x_{4, t}^{2}- \\
& 0.0001067 x_{5, t}^{2}+4854.7012 x_{6, t}^{2}
\end{aligned}
$$

\section{Conclusions}

$\mathrm{CO} 2$ emissions per one production unit depend on the previous period. The dependency is positive, which means the more emissions there are during the current period, the more there will be in the next one. The endogenous parameter is also affected by another parameter - deforestation. It should be noted that the dependency between them is negative, both in current and previous periods, which shows that with deforestation, $\mathrm{CO} 2$ emissions per one production unit increases. The indices - the volume of freight traffic and the volume of producing and reprocessing energy were excluded from the analysis due to their strong correlation with other exogenous variables, therefore they are not available in the equation. The rest of the variables signified the following influence on the volume of $\mathrm{CO} 2$ emissions. The indices of the transport and communication industries as well as the capacity of the natural resources industry when increasing lead to an increase in $\mathrm{CO} 2$ emissions. The indices of the roundwood production as well as expanding the road system, on the contrary, lead to emissions decrease. Previous periods of all exogenous parameters, except for the index of deforestation, do not influence the endogenous variable. 
The paper is based on research carried out with the financial support of the grant of the Russian Science Foundation (Project No. 14-38-00009. The program-targeted management of the Russian Arctic zone development). Peter the Great St. Petersburg Polytechnic University.

\section{References}

1. G.M. Grossman, A.B. Krueger, Environmental Impacts of a North American Free Trade Agreement (NBER Working Paper3914, 1991)

2. R. Lopez, J. Environ. Econ. Manage, 27, 163 (1994). DOI: http://dx.doi.org/10.1006/jeem.1994.1032

3. K.E. McConnell, Environ. Develop. Econ., 22, 383 (1997). DOI: https://doi.org/10.1017/S1355770X9700020X

4. J. Andreoni, A. Levinson, J. Pub. Econ., 80, 269 (2001).http://econweb.ucsd.edu/ jandreon/Publications /JPubEKuznets.pdf

5. G.M. Grossman, A.B. Krueger, Q. J. Econ., 110, 353 (1995). DOI: https://doi.org/10.2307/2118443

6. A.B. Chimeli, J.B. Braden, Environ. Develop. Econ., 14, $541 \quad$ (2009). DOI: https://doi.org/10.1017/S1355770X08004981

7. B. Lahiri, East. Econ. J., 43, 104 (2017). DOI: 10.1057/eej.2015.3

8. N.L. Stokey, Inter. Econ. Rev., 39, 1 (1998). DOI: $10.2307 / 2527228$

9. G. May, B. Stahl, M. Taisch, Appl. Ener., 164, 628 (2016). http://dx.doi.org/10.1016/j.apenergy.2015.11.044

10. X. Xu, A global perspective, World Dev., 27, 1215 (1999). DOI: http://dx.doi.org/10.1016/S0305750X(99)00055-8

11. A. Levinson, M.S. Taylor, Int. Econ. Rev. (Philadelphia), 49, 223 (2008). DOI: http://dx.doi.org/10.1111/j.1468-2354.2008.00478.x
12. P.E. Karlsson, J. Klingberg, M. Engardt, C. Andersson, J. Langner, G.P. Karlsson, H. Pleijel, Scien. Tot. Environ., 576, 22 (2017). DOI: 10.1016/j.scitotenv.2016.10.061

13. E. Botta, T. Koźluk, OECD iLib (2014). DOI: http://dx.doi.org/10.1787/18151973

14. G.Y. Liu, Z.F. Yang, B.D. Fath, L. Shi, S. Ulgiati, Appl. Ener., 186, 96 (2017). DOI: 10.1016/j.apenergy.2016.06.132/

15. H.D. Robison, Can. J. Econ., 21, 187 (1988)

16. J. Ederington, J. Minier, Can. J. Econ., 36, 137 (2003). DOI: http://dx.doi.org/10.1111/15405982.00007

17. M.A. Cole, R.J.R. Elliott, J. Environ. Econ. Manage, 46, 363 (2003). DOI: http://dx.doi.org/10.1016/S0095-0696(03)00021-4

18. G. Arce, L.A. López, D. Guan, Appl. Ener., 184, 1063 (2016). DOI: http://dx.doi.org/10.1016/j.apenergy.2016.05.084

19. J. Meng, J. Liu, S. Guo, Y. Huang, S. Tao, Appl. Ener. $184, \quad 853 \quad$ (2016). DOI: http://dx.doi.org/10.1016/j.apenergy.2015.09.082

20. T. Sakamoto, S. Managi, Appl. Ener., 185, 615 (2016). DOI: 10.1016/j.apenergy.2016.10.126

21. R.T. Carson, Rev. Environ. Econ. Pol., 4, 3 (2010). DOI: https://doi.org/10.1093/reep/rep021

22. E. Vyboldina, A. Cherepovitsyn, S. Fedoseev, P. Tsvetkov, Ind. J. Scien. Technol., 9 (2016). DOI: 10.17485/ijst/2016/v9i5/87633

23. N. Didenko, D. Rudenko, D. Skripnuk, International Multidisciplinary Scientific GeoConference Surveying Geology and Mining Ecology Management, SGEM, 3, 267 (2015)

24. P. Tcvetkov, A. Strizhenok, J. Ecolog. Engineer., 17, 56 (2016). DOI: 10.12911/22998993/61190

25. D. Rudenko, N. Didenko, Proceedings of the 3rd International Conference on European Integration, 2016 